Volume 3

Number 1 Critical Perspectives on Marketing

from Japan - Part 1

Article 3

2018

\title{
From Social Marketing to Societal Perversion: History of \\ Hometown Tax in Japan
}

Yuichiro Hidaka

Okayama University

Kosuke Mizukoshi

Tokyo Metropolitan University

Follow this and additional works at: https://digitalcommons.uri.edu/mgdr

Part of the Anthropology Commons, Economics Commons, Geography Commons, Marketing Commons, Other Business Commons, Political Science Commons, and the Sociology Commons

\section{Recommended Citation}

Hidaka, Yuichiro and Mizukoshi, Kosuke (2018) "From Social Marketing to Societal Perversion: History of Hometown Tax in Japan," Markets, Globalization \& Development Review. Vol. 3: No. 1, Article 3.

DOI: 10.23860/MGDR-2018-03-01-03

Available at: https://digitalcommons.uri.edu/mgdr/vol3/iss1/3

This Article is brought to you for free and open access by DigitalCommons@URI. It has been accepted for inclusion in Markets, Globalization \& Development Review by an authorized editor of DigitalCommons@URI. For more information, please contact digitalcommons-group@uri.edu. 
From Social Marketing to Societal Perversion: History of Hometown Tax in Japan

Cover Page Footnote

The authors are grateful to MGDR editor Nikhilesh Dholakia and to MGDR reviewers for detailed help in the development of this paper. 


\section{Markets, Globalization \& Development Review}
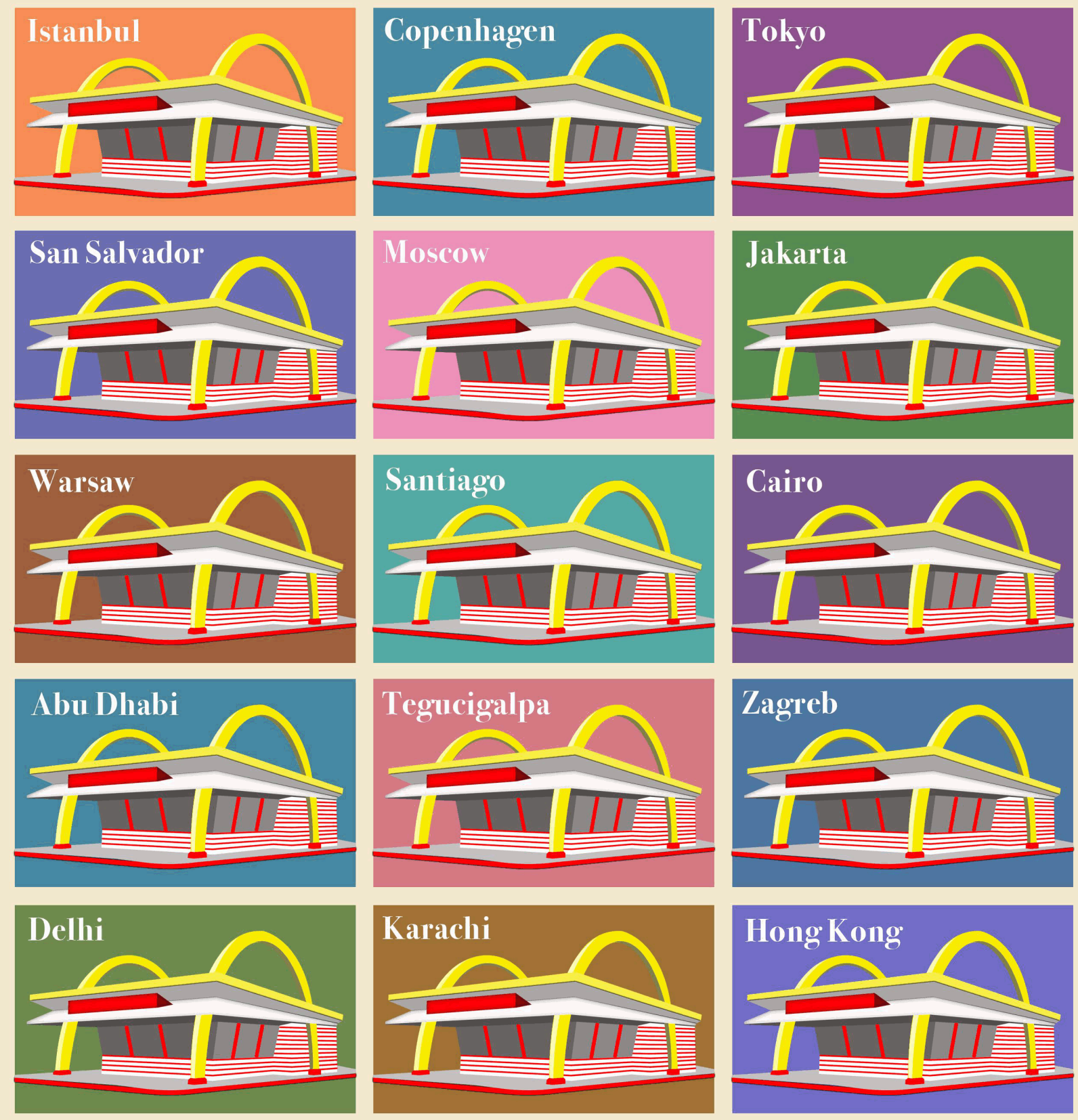

This article is available in Markets, Globalization \& Development Review: https://digitalcommons.uri.edu/mgdr/vol3/ 


\section{From Social Marketing to Societal Perversion: History of Hometown Tax in Japan}

\section{Introduction}

Social expectations from marketing have increased in the recent past (Kotler and Lee 2006; 2009). Marketing can be used to spread messages ranging from avoiding smoking hazards, promoting good diet, or cementing friendship; to - of course - selling soap. Individual behavioral change and social change are other important goals of marketing and marketing research (Kotler, Kartajaya and Setiawan 2010). Ever since the late 1960s (Kotler and Levy 1969; Kotler and Zaltman 1971), the marketing concept has been widening its scope.

Social marketing research has pointed out that interventions for individual behavioral change and social change are important (Andreasen 1994; 2002; 2012). Recently, the interventions for upstream activities (Gordon 2013) and systems thinking (Domegan et al. 2016; Layton 2007) have also been considered important. In particular, government-led social marketing - where social marketing is actually applied by state entities - is seen as a necessary addition to policymaking (Kennedy 2016; Troung 2016).

It is worth noting that social marketing advocates social good. Critical social marketing research, on the other hand, has attempted to reconsider the theoretical assumptions of social marketing research (Tadajewski 2013). In reality, it is difficult to know whether the social good, of the type acknowledged by the entire society, exists. Intended 'social good' may sometimes be just a justification of programs. The interventions for behavioral change or social change, in our view, should not be affirmed automatically, nor should they be accepted uncritically. We should consider how and why the stakeholders involved need these interventions, how they actually engage in various interventions, and how they may create conflicts in realizing the social good. In critical social marketing research (e.g., Varman, Skålén and Belk 2012), effective methods of interventions are not the prime focus but effects of governmentality or other potentially conflict-laden processes are explored.

This paper considers competition among municipalities over attracting donations in the Japanese hometown tax system, which was introduced under the name of local revitalization in Japan. Hometown tax has dramatically increased donations to municipalities. On the other hand, it has developed a quasi-market and quasi-competition over reciprocal gifts for the "donors." Some local industries in each region have been 
motivated to support hometown tax and it has become a more attractive system for affluent people with high investment abilities. The Japanese government, which is typically neoliberal, has used the market system to do the governmental work of collecting and reallocating taxes. In addition, in Japan, there is a general preference for political powers to work behind the scenes. Such a less-than-transparent culture also causes concerns over governmentality.

The findings in this study indicate that when social marketing attempts to carry out more effective macro-level interventions, societal perversion can sometimes occur. This implication provides critical and important insights for social marketing research. In particular, we should pay attention to governmentality rather than direct and compulsory interventions, which have been considered important in social marketing. It means that social marketing could get coopted into the network of neoliberal governmentality. It is important for social marketing to apply commercial marketing and pursue the identity of social marketing, but we should reflect on how such ideas interact with the premise of neoliberalism.

In the following sections, we consider the history of hometown tax in Japan. Further, we review social market research and critical market research, and observe the history of hometown tax from both viewpoints. Finally, we examine the influence of neoliberal governmentality in social marketing and social marketing studies.

\section{Brief History of Hometown Tax in Japan}

\section{Research Context and Methodology}

This research offers insights on social marketing by the governments (Kennedy 2016; Truong 2016) and the collective-conflictual value cocreation (Laamanen and Skålén 2015) between the ideal intention of the government, and competition among municipalities in practice, through the history of hometown tax of the Japanese government to solve social problems in rural municipalities.

Hometown tax in Japan is a unique system in which people can donate to municipalities by freely selecting their payees, under certain conditions, and donors in turn receive tax benefits. The Japanese government introduced this system in 2008 to correct the tax revenue gap between rural municipalities and cities. The initial intention of the Japanese government was to revitalize rural municipalities that had suffered from chronic financial challenges. The overall amount and the number of cases of donations through hometown tax have increased dramatically as indicated in Figure 1. 
In this research, quantitative data on the number and amounts of donation that each municipality received through hometown tax is based on statistics obtained from the Ministry of Internal Affairs and Communications. In addition, qualitative data is obtained from the Diet (Japanese Parliament) Records, as well as a database of Japanese newspaper articles after 2007 that contained the word "hometown tax." We chose to rely on newspaper articles as they reflect the complete picture of public opinions surrounding hometown tax (Gamson and Modigliani 1989). Finally, we conducted interviews with the Japanese government, municipalities, and consulting agencies that were involved heavily in hometown tax.

\section{Initial Intention of Hometown Tax}

Hometown tax was introduced in April 2008. Under this system, people can select their favorite municipalities based on their free will. Hometown tax is not a direct tax payment system to the preferred municipalities, but a donation system to municipalities. Therefore, donation was subject to tax deduction in the following fiscal year under a certain limit. It was a trick used to diffuse widely the adoption of hometown tax.

The initial intention of the Japanese government was to correct the tax revenue gap between rural municipalities and cities through competition among municipalities. Traditionally, in Japan, finances of rural municipalities were primarily covered by local allocation tax from the government. The government, however, promoted integrated administrative and financial reforms that included the reform of the government subsidy, decentralization by transferring tax sources, and reducing of local allocation tax in the first decade of the $21^{\text {st }}$ century (Uchiyama 2013). As a result, the amount of local allocation tax decreased and rural municipalities with small populations lost local allocation tax, while urban areas with large populations were able to secure sufficient tax revenues on their own. Following this loss of revenue, some rural municipalities requested the government to introduce the hometown tax idea (Nishikawa 2009).

Through various adjustments, the government decided to relax the regulation and introduce the hometown system as a method of tax redistribution. As significant part of this system, the government emphasized that this voluntary tax be a tool to solve social problems in each municipality based on self-help efforts and the donor's free will, thereby strengthening of the bonds between donors and rural towns, and promotion of the hometown tax payment as a social good. People could begin to contribute to their preferred municipalities freely under this system. 
Figure 1: Number of Cases and Amount of Hometown Tax

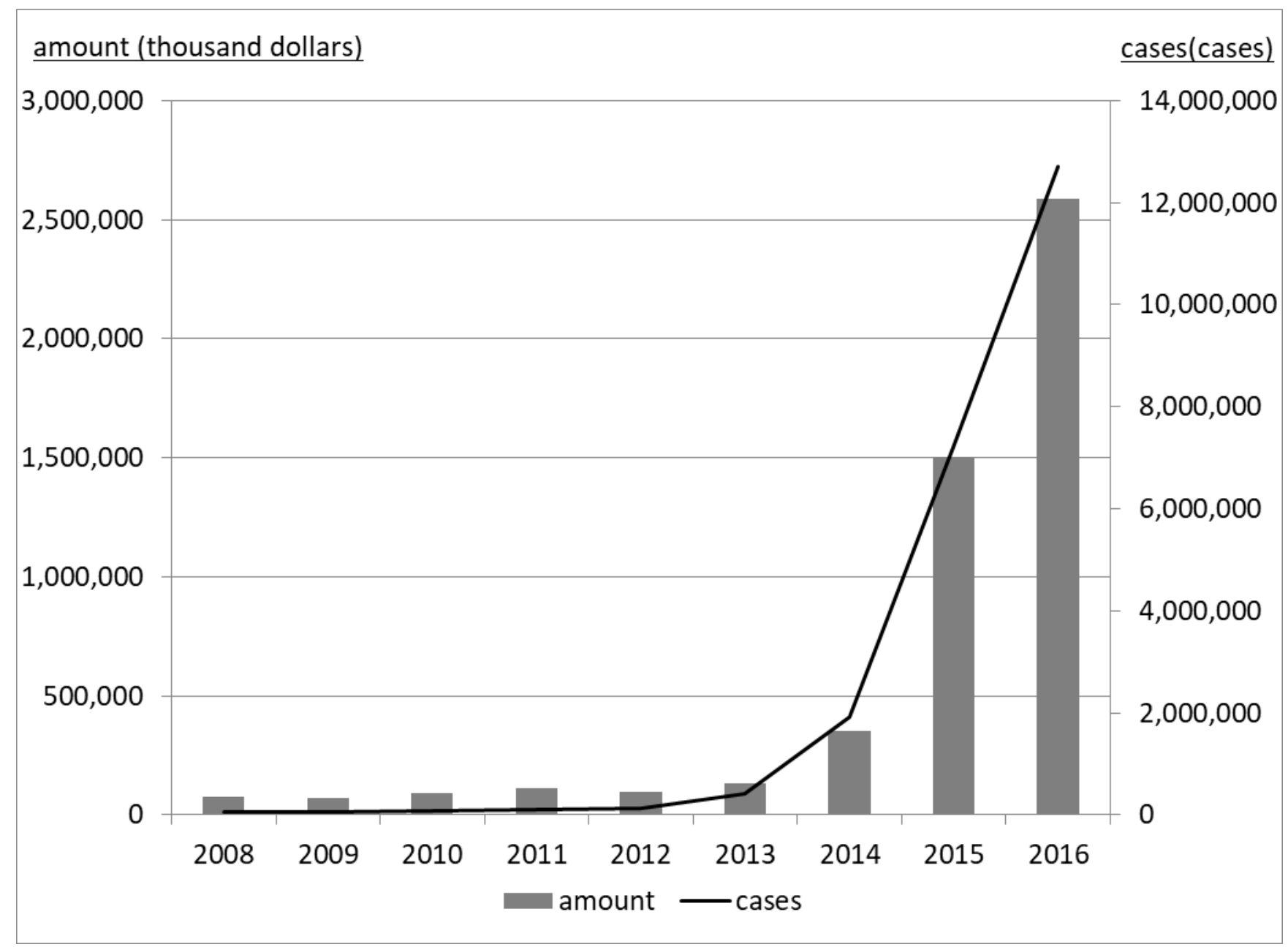

\begin{tabular}{|l|r|r|r|r|r|r|r|r|r|}
\hline & \multicolumn{1}{|c|}{2008} & \multicolumn{1}{c|}{2009} & \multicolumn{1}{c}{2010} & \multicolumn{1}{c|}{2011} & \multicolumn{1}{c|}{2012} & \multicolumn{1}{c|}{2013} & \multicolumn{1}{c|}{2014} & \multicolumn{1}{c}{2015} & 2016 \\
\hline cases & 53,671 & 56,332 & 79,926 & 100,861 & 122,347 & 427,069 & $1,912,922$ & $7,260,093$ & $12,710,780$ \\
\hline change yoy & - & 1.05 & 1.42 & 1.26 & 1.21 & 3.49 & 4.48 & 3.80 & 1.75 \\
\hline amount & 73,996 & 69,979 & 92,888 & 110,569 & 94,637 & 132,396 & 353,202 & $1,502,646$ & $2,585,535$ \\
\hline change yoy & - & 0.95 & 1.33 & 1.19 & 0.86 & 1.40 & 2.67 & 4.25 & 1.72 \\
\hline
\end{tabular}

Source: Open Public Source Data, Ministry of Internal Affairs \& Communications

unit:cases(cases)/amount(thousand dollars)

Initially, several municipalities solicited donations purely for their social problems. In 2011, due to the earthquake in Japan, some municipalities gathered donations temporarily. They were, however, 
unable to gather significant donations. As a result, the idea of hometown tax did not diffuse widely.

\section{Rapid Diffusion of Donations through Competition}

Around the year 2013, hometown tax collections started to increase. This was owing to the fact that certain pioneering municipalities applied commercial marketing frameworks to their strategy for the acquisition of donations, developed their marketing strategy centered on reciprocal gifts, and began to collect large amounts of donations. They collaborated with local enterprises in their region to provide reciprocal gifts to donors and actively initiated their marketing strategy to gain donors. Using the tax deduction system, donors could receive generous reciprocal gifts, with only a marginal payment burden. Simultaneously, local municipalities could actively promote their unique local products and tourism. From the viewpoint of municipalities, the revitalization of local industries and tourism was also the issue in the resolution of regional social problems, which was an intended goal of the hometown tax system.

These efforts attracted significant attention from other municipalities. Pioneering municipalities received many inquiries from other municipalities that wanted to actively gather donors. The pioneer municipalities shared their knowhow with the follower municipalities.

The influence of consulting companies also supported this diffusion. They positively shared marketing methods with each municipality, proposed the strategy to differentiate potential resources in each municipality, and conducted marketing research based on the donor's needs and wants. Some consulting companies started web catalogue services for donors who expected reciprocal gifts. In such services, people could select their preferred reciprocal gifts effectively and freely, similar to online shopping. The information of these orders was sent to each municipality and the delivery systems were also set up. Some consulting companies provided outsourcing services, such as undertaking receipt of orders and delivery of reciprocal gifts.

These efforts were reported largely by the mass media. The media proactively suggested to the municipalities that donors could receive a handful of reciprocal gifts. This exposure in the media raised the recognition of the hometown tax system and it simultaneously created a chance for taxpayers to pay particular attention to reciprocal gifts.

In this manner, the marketing strategy centered on reciprocal gifts for donor acquisition was transferred quickly to other municipalities and the competition for donor acquisition became more intense. The main competition over donations was focused on reciprocal gifts. Each municipality enlisted various gifts. Rice, Sake, brand-name beef, crabs, 
fine fruits, traditional crafts, and travel tickets among others appeared as reciprocal gifts. For example, a local municipality with a population of 36,000 gathered $\$ 12.7$ million donations in 2014 by offering specialty seafood as gifts. Another local municipality with a population of 165,000 gathered donations of $\$ 38$ million in 2015 and $\$ 66.7$ million in 2016 by offering brand-name beef and alcohol as gifts. The number of municipalities whose donations through hometown tax payment accounted for more than $10 \%$ of their finances increased from 12 in 2014 to 149 in 2016.

While notifying municipalities of the appropriate operation of this system, the government urged people to utilize this system actively by raising the tax deduction limit and simplifying the deduction procedures in 2015. The payment methods, such as credit card acceptance, also expanded. The municipalities further expanded the assortment of their reciprocal gifts and raised the ratio of the amount of gifts to the donation amount.

In this manner, hometown tax dramatically increased donations to municipalities on the one hand and, on the other hand, developed a quasimarket and quasi-competition over reciprocal gifts. The media proactively reported the high ratio of gifts to donation amounts. Eventually, of course, the debates on the pros and cons on lavish gifts arose. Two major advocates supported this expansion. The first group of advocates were the local industries and tourism services in each municipality, the main providers of reciprocal gifts. For them, hometown tax became an unintended promotional measure as the municipalities purchased their products at a stable price and promoted tourism. Hometown tax was attractive to many local municipalities mainly from the viewpoint of revitalization of the local industry and tourism. The second group of advocates were a majority of the taxpayers who regarded sufficient gifts as cost effective products. For them, hometown tax was an efficient method to obtain specialty goods and tourism at a lower cost. Particularly for affluent people who had high capability to invest in the market, hometown tax payment became a useful tax saving measure - while enjoying fine reciprocal gifts.

\section{Intervention of the Government for Re-regulation}

The initial intention of hometown tax was to correct the tax revenue gap between rural municipalities and cities, and to provide people a method to bring cheer to local regions that faced financial challenges to solve their social problems. In the initial version, the role of donations for resolving social problems was regarded as secondary. Although the total amount of donations increased, much of these 'tax receipts' turned into expenses for 
reciprocal gifts and for future marketing. Municipalities prepared donation programs mainly to resolve their social problems, but - in comparison to the expenses for reciprocal gifts - the municipalities did not draw sufficient attention to local problems or collect sufficient donations.

The national government had certainly predicted, to a certain extent, the potential disadvantages of reciprocal gifts. In the beginning, however, to encourage the rapid diffusion of this system, these gifts were not regulated. Over time, the doubts about lavish gifts given to the donors intensified as the competition over gifts intensified. The government issued notices to prevent municipalities from giving excessively luxurious gifts, goods with high exchangeability, and goods that had high value as assets in particular years (in 2014, 2016, and 2017).

In response to this notification, some municipalities stopped acquiring donations by offering expensive gifts. Some other municipalities promoted a strategy to encourage donors that they gained through reciprocal gifts to donate to programs purely for social problem resolution without gifts. In addition, some consulting companies promoted voluntary regulation and conducted public awareness activities for the appropriate operation of hometown tax in order to maintain this system.

There is a persistent opposition from municipalities to such regulatory notifications from the central government. Every time the government issues a notice, some heads of municipalities issue opposing comments. Against this background, there is a positive view that fulfilling gifts are another means of regional revitalization, particularly from the perspective of industry promotion. Also, a concurrent and aggressive discourse emphasizes the significance of reciprocal gifts, often in the form of "buy local for revitalization" exhibitions and shows.

Hometown tax makes a contribution in terms of expanding the municipal revenue sources in rural areas. In addition, the understanding of donation to purely solve social problems is progressing gradually. However, the center of competition remains reciprocal gifts.

\section{Social Marketing Perspective}

\section{Social Marketing Research for Effective Interventions}

Social marketing is generally regarded as an effective approach to improving social good in the field of public health (smoking cessation, alcohol abuse prevention, better nutrition), environmental protection (waste reduction, energy use reduction), family planning, and poverty alleviation among others (Achrol and Kotler 2017; Dholakia 1984; Kotler and Lee 2009; Truong 2014). Traditionally, social marketing research has 
mainly discussed individual behavior change through effective interventions (Andreasen 1994; Hastings, Angus and Bryant 2011).

The origin of social marketing research is the application of commercial marketing (Kotler and Levy 1969; Kotler and Zaltman 1971), particularly the marketing mix, to social programs (Peattie and Peattie 2009). Clearly, the application of marketing mix to achieve social goals has been accepted widely, despite some criticism from the viewpoint of the historical derivation of marketing mix (Gordon 2012). Considering this, the social marketing benchmark criteria (Andreasen 2002) were set up to understand social marketing projects and identify the common elements that make projects more effective. Social marketing research has mainly discussed the effectiveness and efficiency of social marketing interventions based on these frameworks (Andreasen 2002; Kenny and Hastings 2011). Such studies focused strongly on the individual behavioral change of the target audiences and discussed mainly the "downstream" activities, in which the direct effects of interventions on target audiences are of interest (Dann 2010; Dibb and Carrigan 2013).

Although these research studies seek to understand the effectiveness of social marketing interventions on target audiences, it is challenging to deepen the understanding of the process in which 'wicked social problems' become socially problematic, and managing the process of organizing and developing social movements that improve the society (Goldberg 1995; Gordon 2013). Basically, the fundamental solution of social problems should require the social establishment of individual behavioral change. This has required the shifting of attention to some of the "upstream" activities, the interventions that attempt to influence the actors who are involved in the social structure, such as public policy, regulations, and social norms (Dann 2010; Goldberg 1995; Gordon 2013; Hoek and Jones 2011; Wymer 2010).

The focus on the upstream rather than the downstream suggests that we need to understand individual behavioral change in the social context as a part of social change (Dibb 2014, pp.10-14; Luca, Hibbert and McDonald 2016, pp.3-4). This indicates that it is important to extend the understanding from a one-shot perspective to a comprehensive perspective that focuses on social change in order to understand the effectiveness of multiple interventions on the target audiences (Andreasen 2006; 2012).

With the addition of an upstream focus, research on social marketing interventions by the government has advanced. The interventions by the government are regarded as important contributors of social change (Domegan 2008; Donovan 2011); after all, there is a limit to 
realizing individual behavior change by individuals alone due to the limited information or limited information processing ability (Hoek and Jones 2011; Truong 2016; Wymer 2010).

Macro-social marketing is "the use of social marketing by governments and other upstream actors within a systemic approach to engender social change" (Truong 2016, p.2). The focus of macro-social marketing is social change through interventions by the government (Dholakia 1984; Domegan 2008; Donovan 2011; Kennedy and Persons 2012; Truong 2016; Wymer 2010).

Kennedy and Parsons (2012) consider the case of the Canadian government's interventions in smoking cessation and indicate that it is an important research issue in macro-social marketing research to understand the linkage between intervention by governments and downstream activities. Kennedy and Parsons (2012) make an important contribution by developing the theoretical foundation of macro-social marketing. Based on Kennedy and Parsons (2012), Kennedy (2016) and Truong (2016) present theoretical frameworks of macro-social marketing with reference to systems theory and institutional theory.

Truong (2016) discusses 57 interventions by the Vietnamese government for smoking cessation, helmet use, drunk-driving prevention, and nutrition. Applying the social marketing benchmark criteria that have been used in the downstream contexts, Truong (2016) considers the programs that are regarded as social marketing interventions by the government, and presents the government-led macro-social marketing model. Interventions by the governments often lead to conflicts and failures. Truong (2016) indicates that government-led social marketing may not be sufficient to create social change in Vietnam, though its role is important for social change. Regardless of the laws and policies, the results can change significantly, depending on the understanding or operations in the practice sites. The interventions by the governments do not promote social change unilaterally. Many of them do not function because of lack of understanding; are at times understood in unexpected ways; and may cause unintended consequences (Peattie, Peattie and Newcombe 2016). Truong (2016) indicates that the linkages - of interventions across macro-social marketing on a national level, upstream marketing on an institutional level, midstream marketing on a community level, and downstream marketing on an individual level - are important to generate social change. For example, in case of helmet use, the relationship among the stakeholders surrounding social problems, such as the crackdown and cooperation with manufacturers and importers of helmets, is an important component of social marketing intervention. 
These research studies identify the components of the interventions by governments and indicate certain important factors to bring about social change - in practiced reality - from a social construction perspective.

\section{Insights from the Social Marketing Perspective}

Based on the social marketing perspective, we may be able to obtain certain insights about the hometown tax in Japan. In the following, we attempt such an explanation.

The first insight is that the interrelationship between the interventions of the government and social marketing by individual municipalities accelerates social change. Initially, the idea of hometown tax was conceived by some local municipalities and 'marketed' upstream to the national government. Hometown tax, however, did not become a familiar method. The donations became popular only after municipalities proactively promoted the hometown tax idea downstream, to affluent individuals, and competed with each other by implementing strategies based on commercial marketing frameworks. The competition in downstream dimensions encouraged further government interventions. What was observed in Japan is consistent with existing research (Kennedy and Parsons 2012; Kennedy 2016; Truong 2016) that has indicated that social change is effectively promoted by linking the upstream, downstream, and government interventions - although the outcomes are at times different from the original intention of the government.

The second insight is that economic incentives, such as reciprocal gifts or competitions, are important underpinnings that accelerate systemwide social change. These economic incentives promote social change by encouraging donor's decision-making based on their free will. The economic incentives are considered to play an important role as the linkage with other social marketing interventions, such as taxation, is important for social change, as Kennedy and Parsons (2012) indicate.

The intense competition over reciprocal gifts increased the number of donors and the donation amount in the downstream phase. Simultaneously, in the upstream phase, it increased the pros and cons debate, and induced further interventions, such as tax reforms and reregulations by the government.

Further work to develop the conceptual underpinnings in macrosocial marketing has been pointed out as an important research issue (Truong 2016, p. 14). This case shows that economic incentives, such as reciprocal gifts or competition among municipalities, not only revitalizes downstream marketing for individual targets, but also strongly influences 
social change by promoting the interrelationship between government interventions and individual social marketing.

The third insight is that it is important to create a relationship not only with donors but also with upstream stakeholders, such as local municipalities, local suppliers, and tourism - in order to increase the effect of government interventions.

As existing research has indicated (Dann 2010; Goldberg 1995; Gordon 2013), upstream stakeholders strongly influence social change. Hometown tax diffused widely via the cooperation, particularly of local industries and tourism services in each municipality, and strong support from them relating to reciprocal gifts were the driving forces for the diffusion. This was a major reason why the promotion of the hometown tax advanced the revitalization of regional economies and enhanced public welfare. Social change was realized based on the upstream stakeholders involved; but with the linkage of active downstream efforts.

\section{Critical and Macromarketing Perspective}

\section{Social Marketing Mechanism}

By utilizing social marketing knowledge fully, it is possible to anticipate rural activation and increase in donations. These are important activities for the realization of social good but, on the other hand, there is a possibility that a simple social marketing perspective obscures the conflicts and negative aspects in realizing social good. It is also indispensable for social marketing research to pay attention to the structure that supports various activities related to the hometown tax system.

Critical marketing studies are "concerned with challenging marketing concepts, ideas and ways of reflection that present themselves as ideologically neutral or that otherwise have assumed a taken-forgranted status" (Tadajewski 2013; Tadajewski 2011, p. 83). Conventional managerial marketing and exchange concept reveal that their ideologies are based on neoliberalism (Skålén and Fellesson 2012). Similarly, service dominant logic and value co-creation, which have attracted attention in recent years, have assumed harmony and mutual benefit, and are regarded as an uncritical "good" (Vargo and Lusch 2004; 2008). On the other hand, Laamanen and Skålén (2015) address collective conflict such as destruction (Echeverri and Skålén 2011) and exploitation (Bonsu and Darmody 2009; Cova and Dalli 2009; Zwick, Bonsu and Darmody 2008) - in the interactions of value co-creation.

Social marketing is also subject to criticism. Originally, social marketing had a critical viewpoint on managerial marketing (Arnold and 
Fischer 1996; Gordon 2011). For example, emphasis on corporate social responsibility revealed problems of capitalism, such as negative externalities, that commercial marketing had ignored. Social marketing that seeks social responsibility for such companies, however, also needs to be reconsidered from a critical perspective. Particularly, social marketing - based on the premise of intervention - has problems of paternalism and manipulation, including in public and non-profit organizational activities (Moor 2011; Szmigin et al. 2011). Furthermore, in the actual activities, it is also necessary to focus on the capitalist's activities to promote social change based on economic interests (Dholakia and Dholakia 2001).

The latter problem can be considered as a macromarketing issue. Actors - essentially multi-stakeholders with economic interests - are also responsible for individual behavior change and social change, with the aggregate result being changes in the macro phenomena (Hastings 2003). Such issues require more critical marketing perspectives than observable so far. How and why are such interventions, with the potential for paternalism, considered necessary and important in social marketing, and how and why are commercial marketing techniques required in the interventions? Critical social marketing does not present alternative measures to replace social marketing as paternalism and applied commercial marketing techniques. The purpose of critical social marketing is to analyze the actual experiences premised on paternalism, to possibly weaken the influence of paternalism and seek more grassroots voices, and show alternative possibilities in the social marketing activities.

Based on Foucault's concept of governmentality, Varman et al. (2015) grasp the problem of pursuit of profit seeking and poverty alleviation in India's Bottom-of-Pyramid (BOP). The activities of pursuit of profit tied to neoliberalism was initially considered to have produced outstanding results by positively bringing BOP segments into the market, and move toward poverty alleviation. One consequence is that people who cannot survive competition in the market mechanism and the poor who cannot access the actors represented by the system for participating in the marketplace, continue to exist or even expand, and only some people and companies receive benefits from the market. These conflicts are observable in practice, as well as in discourses. Critical perspectives are needed to seek resolutions to such conflicts.

\section{Insights from the Critical and Macromarketing Perspective}

In the process of spreading hometown tax system, it is possible to observe radicalization of donation competition influenced by neoliberalism governmentality. First, the introduction of hometown tax system is 
triggered by the problem of uneven population. Governmentality is not exercised directly on people's abilities and customs, but is exercised on the "population" (Foucault 2007; Walters 2012). For governmentality, population is a concrete object, which has its own elements. Institutional design by the government does not force anything on the local governments and people. In the Japanese case, other actors had the freedom of whether or not to use the options offered by neoliberal hometown tax policies. Therefore, it seems that the system did not spread too much at first.

The donation itself is socially correct and may lead to the revitalization of the region. On the other hand, its realization was accelerated by the formation of a reciprocal gift market that encouraged donation. In this quasi-market, companies as well as the public also acted and competed for profit seeking (Fairclough 1993; Skålén et al. 2012). By establishing complicity with each other, hometown tax became a significant - and of course skewed - quasi-market.

In critical marketing research and macromarketing research, the division of company and consumer is often maintained, and the logic of capital of the company is subject to criticism. Society and consumers are unconsciously regarded as victims. However, as Foucault's governmentality shows, neoliberalism erodes both sides and they are both led to act in the hope of achieving (oft-illusory) gains. The marketing concept also has this tendency (Marrion 2006; Skålén et al. 2012). Many of the current societies do not explicitly consider the simple composition that there is a hegemony of minority governing interests and a mass ideology against it. On the contrary, in most social and political discourses, hegemony is latent and even the opposing ideology may be guided, shaped, and led by hegemony.

Certainly, not all participants will receive equal results. For example, for the general public, qua potential donors, it is the amount of tax payment that becomes a resource of participation. People who pay high taxes are high-income individuals and the revitalization of the quasimarket is in agreement with the tax-saving activity of high-income individuals, and the benefits to low-income groups are relatively small. Municipalities must also be both content and disappointed by the competition. In the past, subsidies that were stably allocated by the national government have changed into competitively sought funds, under the name of donation. After initial experiences with the hometown tax, some municipalities declared that they would abandon reciprocal gifts and withdraw from competition. If they follow this approach, they are at the risk of losing donations. Regardless of the adverse rate of donation-to-gift, 
those who participate in the market can expect profits. In relatively big cities, a large population does not directly lead to the stability of capital. The fact that the population is large means that the risk of losing is also significant, depending on their profit seeking behavior through donations. Tokyo has repeatedly reported problems of the hometown tax system owing to such losses.

The workings of power do not fully internalize actors, such as individuals and municipalities (Walters 2012). Governmentality considers that whatever huge and powerful actors rise to the top, such ascent is built on complex networks. Above all, social marketing activities of local governments became possible - and even accelerated - as hometown tax system became an established institution. Furthermore, ignoring this system is not easy now, because of various factors. These factors include declining population and the concomitant financial challenges for several years. Because of the continuing need for revitalization of regional economies, the spread of marketing skills has become important to local governments.

Individual selfish behavior is also marginally different from discipline based on the Foucauldian concept of panopticon, the all-seeing but restraining system created by the actors' networks. Without the system of hometown tax system, no one could have linked donation and profits. Individuals are able to seek profits as local municipalities compete to organize gifts and Internet services provide an online shopping-style interface. In the recent years, some municipalities have proceeded with the establishment of a direct channel that seeks repeated transactions from individuals who previously donated; however, this method has not yet spread widely. This method is akin to Customer Relationship Management or CRM technology, and it could develop as a means to motivate and control donation behaviors.

Even in critical social marketing, the importance of actor network theory has been emphasized (Waters 2012). In the process called translation, the behavior of the actors change due to problematization, interessement (locking actors into specified roles), enrolment, and mobilization. Once a problem is built in the self-evident reality, various actors appear around the problem and rebuild new realities.

Therefore, neoliberalism is not completely and automatically reproduced. Rather, in maintaining neoliberalism, diversity - including criticism - is required. For example, the growth of a quasi-market also promotes pure (selfless, voluntary, societally-oriented) donations that appear to be a deviation from neoliberalism. However, pure donation is also a new "differentiation" for people, as well as for companies and local 
governments. People do not seek profit maximization at all times. Similarly, in this Japanese case, excessive quasi-market activities through collected downstream marketing triggered government regulation. This can be considered as government-led de-marketing. By setting selfimposed restrictions on corporate groups and municipalities, these actions attempt to stop the overshoot of the quasi-market. These behaviors are not a sufficiently powerful to counter neoliberalism itself. Wisdom and marketing techniques enable neoliberalism to survive. A truly excessive market formation will destroy the market itself. If neoliberalism becomes pervasive in a totalistic way, every action will be used to advance the actor's respective interests.

This situation does not merely indicate pessimistic consequences that we cannot change. Neoliberalism as 'pervasive neoliberalism' shows that unilateral and compulsive forces do not work. Neoliberalism is flexible, sometimes in good ways and but more often with adverse effects. Therefore, every activity is re-collected by neoliberalism, though simultaneously it can gradually strengthen every activity and can create significant small social good and new possibilities. The emergence of pure donation makes people recognize the value of altruistic donation and provides options even if they are differentiated. Even though the regulations of the government, and self-regulation by municipalities and the industry will eventually affirm the survival of the market, it could provide an opportunity to present a more moderate and healthy method of establishing a quasi-market.

\section{Concluding Observations}

\section{Critical Thinking about Social Marketing}

This paper considers social marketing from a critical perspective, referring to the history of donation system named hometown tax in Japan. Social marketing research has been discussed as a method to realize social good by effective interventions (Andreasen 1994; Hastings, Angus and Bryant 2011). From the viewpoint of social marketing, via this Japanese case, we may be able to provide some implications for effective interventions by the government. The history of hometown tax sheds light on issues such as the interrelationship with downstream social marketing interventions applying commercial marketing strategy, the mediation of economic incentives such as reciprocal gifts, and the creation of relationships with various stakeholders as underpinnings of effective interventions for social good. Essentially, hometown tax has been significantly diffused by these factors and has particularly contributed to the revitalization of some local industries and tourism. 
Simultaneously, however, the interventions to realize individual behavior change and social change itself, which social marketing has premised, should be the subject of critical analysis (Gordon 2011; Tadajewski 2011; 2013). Particularly, the current government-led social marketing can be often implemented under neoliberal governmentality (Foucault 2007; Varman, Skålén and Belk 2012; Walters 2012).

Neoliberal governmentality induces people to act based on their free will through minimal market design rather than by mandatory interventions. Interventions applying commercial marketing are an important governance technique. In order to survive in the market, it is indispensable for municipalities to find their own values and differentiate themselves once the market is established. In addition, municipalities are required to adapt to "customer" needs. Customer information is accumulated and analyzed in each organization. It serves as a signal for the subsequent marketing strategy as well as a signal for organizational change. Once neoliberal governmentality has penetrated and creates actor-network constellations, individuals as well as organizations will continue to change their practice.

The interventions for realizing social good create various conflicts under neoliberal governmentality. From the viewpoint of critical and macro-marketing perspectives, we can explicitly observe the premise of social marketing and can highlight an important side effect produced by social marketing interventions of the governments. Particularly, government-led social marketing has side effects: interventions that are aimed at realizing ideal social good produce other actions that stray away from the ideal social good. The case of hometown tax can be considered as a policy with good intentions, where the Japanese government urged municipalities to compete to acquire donations under this system to realize social good. It resulted in creating a quasi-market and quasi-competition of reciprocal gifts, and its use was corrupted owing to the lavish gifts provided to "donors", and by the clever strategies of some donors to collect benefits and avoid paying taxes. As a result, donation to purely resolve social problems continued to be regarded as secondary. In many cases, the system became a reciprocal compact between rich donors and strong local economic interests. Municipalities with the potential to offer lucrative gifts benefited much more than municipalities without such capabilities.

As such, when social marketing attempts to carry out more effective interventions, which social marketing research has pursued, such societal perversions could occur. This is the inevitable systemic outcome of the ongoing neoliberal methods to privatize government services. Particularly, 
the relationship between social marketing and commercial marketing has become more complex in recent times (Andreasen 2012; Dibb and Carrigan 2013; Dibb 2014). Therefore, while collaborating with various stakeholders in the upstream and coordinating their interests (Goldberg 1995; Gordon 2013; Hoek and Jones 2011; Kenny and Hastings 2011; Wymer 2011), social change can become strongly dependent on private sectors. It is a part of a wider pattern of diversion of resources from public to private sectors.

Compulsive and coercive power does not work explicitly under neoliberal governmentality. Neoliberal governmentality survives regardless of the social good that is actually realized, while sequentially adjusting various conflicts created by excessive economical orders which are governed according to the principles of laissez-faire (Varman, Skålén and Belk 2012). Once the neoliberal governmentality penetrates, all other activities extend it (Özgün, Dholakia and Atik 2017).

This situation does not necessarily lead to pessimistic results. It also suggests that activities toward realizing the ideal social good can gradually advance under such circumstances. In the case of hometown tax, as competition over reciprocal gifts has progressed, attention to donation to purely solve social problems has gradually increased - as a means of differentiation in intense competition. The form of social good is reconstituted in this context. Social change is not only realized in the outcome of a one-off campaign, but also "in the complex, conflicted, and increasingly interdependent world" (Shultz 2007, p. 293). To realize a better society, it is not important to solve all problems as one stable social good, but to marginally expand a variety of possibilities that are in practice. Therefore, it is more important to consider research on the historical process of how such social good is reconstituted in future social marketing research. We need to consider the social constructive perspective that captures the process of realizing the social change through the integration of individual activities (Dibb 2014; Kennedy 2016). For example, actor network theory should be an effective approach to understand how and why social good is realized (Gordon and Gurrieri 2014) under neoliberal governmentality.

\section{Japanese Context}

There is also an implication from the Japanese perspective. For example, governmentality studies have been conducted mainly in the West (Walters 2012). Since government interventions often occur actively in Japan, we may be able to study governmentality in more in-depth ways. The introduction and promotion of various market mechanisms by the government has become an important topic in Japan, in addition to 
hometown tax payment. For example, Hara Kambayashi and Matsushima (2012) show that speculative markets were formed in the online securities market as a result of unintended price competition when deregulation allowing free entry occurred. In addition, Matsumoto and colleagues (2017) indicate the possibility that - as a result of the introduction of a market mechanism called eco-point for environmental problems - social costs increased due to the deviation of demand for solar panels. Critically rethinking the use and promotion of these government-led market mechanisms will become increasingly important in the future.

For research on neoliberal governmentality, research in Japan can present several possibilities. As mentioned above, neoliberalism cannot be a subject that can be entirely ignored. It has the flexibility to improve the society. To realize a better society, it is important to marginally expand a variety of possibilities that are in practice.

In relation to this point, many critical studies have also accumulated over time in Japan (see Elliott, Katagiri and Sawai 2013). For example, in Asada (1983), while capitalism is considered to be a dynamic structure that continues to be exercised by collecting and generating differences, by strengthening the sustainability of the difference, non-capitalists can secure a place. Similarly, Azuma (1998) explains the sustainability of differences using postal metaphor which was introduced by Derrida. Differences, like mail items, may reach the other, or sometimes they do not. Sometimes they accumulate in the dead stock, they may take time to reach. Donations seem the same in hometown tax case. Some donations are involved in the market exchange mechanism, but some other donations are not. Critical studies focus on these 'unreceived mails', and analyze why and how mails stay there.

By utilizing various research insights, western and Japanese, it is possible to consider the types of practices that bring important values to society. It will be more important to understand diverse realities in various ways. Of course, marketing also requires the same diversity of viewpoints. Marion (2006) says 'As marketing doctrine develops through incorporation of criticism, it follows that the critical process is a never-ending one.' 


\section{References}

Achrol, Ravi S. and Philip Kotler (2017), "Extending the Marketing Dialog on Poverty," Markets, Globalization and Development Review, 2 (1), 6. https://doi.org/10.23860/MGDR-2017-02-01-06

Andreasen, Alan R. (1994), "Social Marketing: Its Definition and Domain," Journal of Public Policy \& Marketing, 13 (1), 108-14.

Andreasen, Alan R. (1995), Marketing Social Change. Jossey-Bass.

Andreasen, Alan R. (2002), "Marketing Social Marketing in the Social Change Marketplace," Journal of Public Policy \& Marketing, 21 (1), 3-13. https://doi.org/10.1509/jppm.21.1.3.17602

Andreasen, Alan R. (2006), Social Marketing in the 21st Century. Sage.

Andreasen, Alan R. (2012), "Rethinking the Relationship between Social / Nonprofit Marketing and Commercial Marketing," Journal of Public $\begin{array}{lllll}\text { Policy \& } \quad 31 \quad \text { Marketing, } & \text { 36-41. }\end{array}$ https://doi.org/10.1509/jppm.09.035

Asada, Akira (1987), Structure and Power: Beyond Semiotics, Keso-syobo (in Japanese).

Arnold, Mark J. and James E. Fisher (1996), "Counterculture, Criticisms and Crisis: Assessing the Effect of the Sixties on Marketing Thought," Journal of Macromarketing, 16 (1), 118-33. https://doi.org/10.1177/027614679601600109

Azuma, Hiroki (1998), Ontological, Postal Basis - about Jacques Derrida, Shinchosha (in Japanese).

Bonsu, Samuel K. and Aron Darmody (2008), "Co-creating Second Life: Market-consumer Cooperation in Contemporary Economy," Journal of Macromarketing, $28 \quad$ (4), 355-68. https://doi.org/10.1177/0276146708325396

Cova, Bernard and Daniele Dalli (2009), "Working Consumers: The Next Step in Marketing Theory?," Marketing Theory, 9 (3), 315-39. https://doi.org/10.1177/1470593109338144

Dann, Stephen (2010), "Redefining Social Marketing with Contemporary Commercial Marketing Definitions," Journal of Business Research, 63 (2), 147-53. https://doi.org/10.1016/j.jbusres.2009.02.013

Dholakia, Nikhilesh and Robert W. Nason (1984), "Research Issues in Macro-Marketing: A Blueprint for Progress," European Journal of 
Marketing, 18

(1),

$41-55$. https://doi.org/10.1108/EUM0000000004720

Dholakia, Ruby R. (1984), "A macromarketing perspective on social marketing: The case of family planning in India," Journal of Macromarketing, 4

(1),

53-61. https://doi.org/10.1177/027614678400400106

Dholakia, Ruby R. and Nikhilesh Dholakia (2001), "Social Marketing and Development," in Handbook of Marketing and Society, Paul N. Bloom and Gregory T. Gundlach, eds. Thousand Oaks CA: Sage, 486-505.

Dibb, Sally and Marylyn Carrigan (2013), "Social marketing transformed: Kotler, Polonsky and Hastings reflect on social marketing in a period of social change," European Journal of Marketing, 47 (9), 1376-98. https://doi.org/10.1108/EJM-05-2013-0248

Dibb, Sally (2014), "Up, Up and Away: Social Marketing Breaks Free," Journal of Marketing Management, 30 (11-12), 1159-85. https://doi.org/10.1080/0267257X.2014.943264

Domegan, Christine (2008), "Social Marketing: Implications for Contemporary Marketing Practices Classification Scheme," Journal of Business and Industrial Marketing, 23 (2), 135-41. https://doi.org/10.1108/08858620810850254

Domegan, Christine, Patricia McHugh, Michelle Devaney, Sinead Duanne, Michel Hogan, Benjamin J. Broome, Roger A. Layton, John Joyce, Marzia Mazzonetto and Joanna Piwowarczyk (2016), "SystemThinking Social Marketing: Conceptual Extensions and Empirical Investigations," Journal of Marketing Management, 32 (11-12), 1123-44. https://doi.org/10.1080/0267257X.2016.1183697

Donovan, Rob (2011), "Social Marketing's Mythunderstandings," Journal of Social Marketing, 1 (1), 8-16. https://doi.org/10.1108/20426761111104392

Echeverri, Per and Per Skålén (2011), "Co-creation and Co-destruction: A Practice-theory Based Study on Interactive Value Formation," $\begin{array}{lllll}\text { Marketing Theory, } & 11 & \text { (3), } & \text { 351-73. }\end{array}$ https://doi.org/10.1177/1470593111408181

Elliott, Anthony, Katagiri, Masataka, and Atsushi Sawai eds. (2013), Japanese Social Theory: From Individualization to Globalization in Japan Today, Routledge. 
Fairclough, Norman (1993), "Critical discourse and the marketization of public discourse: The universities," Discourse and Society, 4 (2), 133-68. https://doi.org/10.1177/0957926593004002002

French, Jeff and Ross Gordon (2015), Strategic Social Marketing. Sage.

Foucault, Michel (2007), Security, Territory, Population: Lectures at the College de France 1977-1978, trans., G. Burchell, New York: Palgrave Macmillan.

Gamson, William A. and Andre Modigliani (1989), "Media Discourse and Public Opinion on Nuclear Power: A Constructionist Approach," American Journal of Sociology, 95 (1), 1-37. https://doi.org/10.1086/229213

Goldberg, Marvin E. (1995), "Social Marketing: Are We Fiddling While Rome Burns?," Journal of Consumer Psychology, 4 (4), 347-70. https://doi.org/10.1207/s15327663jcp0404 03

Gordon, Ross (2011), "Critical social marketing: definition, application and domain", Journal of Social Marketing, 1 (2), 82-99. https://doi.org/10.1108/204267611111411850

Gordon, Ross (2012), "Re-thinking and Re-tooling the Social Marketing Mix," Australasian Marketing Journal, 20 (2), 122-26. https://doi.org/10.1016/j.ausmi.2011.10.005

Gordon, Ross (2013), "Unlocking the Potential of Upstream Social Marketing," European Journal of Marketing, 47 (9), 1525-47. https://doi.org/10.1108/EJM-09-2011-0523

Gordon, Ross and Lauren Gurrieri (2014), "Towards a Reflexive Turn: Social Marketing Assemblages," Journal of Social Marketing, 4 (3), 261-78. https://doi.org/10.1108/JSOCM-02-2014-0015

Hastings, Gerald (2003), "Relational Paradigms in Social Marketing," Journal of Macromarketing, 23 (1), 6-15. https://doi.org/10.1177/0276146703023001006

Hastings, Gerard, Kathryn Angus and Carol Bryant (2011), The SAGE Handbook of Social Marketing. Sage.

Hara, Takuji, Norio Kambayashi, Noboru Matsushima eds. (2012), Industrial Innovation in Japan. Routledge.

Hoek, Janet and Sandra C. Jones (2011), "Regulation, Public Health and Social Marketing," Journal of Social Marketing, 1 (1), 32-44. https://doi.org/10.1108/20426761111104419 
Kennedy, Ann-Marie and Andrew G. Parsons (2012), "Macro-social Marketing and Social Engineering: A Systems Approach," Journal of Social Marketing, 2 (1), 37-51. https://doi.org/10.1108/20426761211203247

Kennedy, Ann-Marie (2016), "Macro-social Marketing," Journal of $\begin{array}{llll}\text { Macromarketing, } & 36 & \text { (3), } & \text { 354-65. }\end{array}$ https://doi.org/10.1177/0276146715617509

Kenny, Patrick and Gerard Hastings (2011), "Understanding Social Norms: Upstream and Downstream Applications for Social Marketers," in The SAGE Handbook of Social Marketing, Gerard Hastings, Kathryn Angus and Carol Bryant, eds. Sage, 61-79.

Kotler, Philip and Nancy Lee (2006), Marketing in the Public Sector. Pearson Prentice Hall.

Kotler, Philip and Nancy Lee (2009), Up and Out of Poverty. Pearson Prentice Hall.

Kotler, Philip and Sidney J. Levy (1969), "Broadening the Concept of Marketing," Journal of Marketing, 33 (1), 10-15. https://doi.org/10.2307/1248740

Kotler, Philip and Gerald Zaltman (1971), "Social Marketing: An Approach to Planned Social Change," Journal of Marketing, 35 (3), 3-12. https://doi.org/10.2307/1249783

Kotler, Philip, Hermawan Kartajaya and Iwan Setiawan (2010), Marketing 3.0. John Wiley \& Sons.

Laamanen, Mikko and Per Skålén (2015), "Collective-Conflictual Value Co-creation: A Strategic Action Field Approach," Marketing Theory, 15 (3), 381-400. https://doi.org/10.1177/1470593114564905

Layton, Roger A. (2007), "Marketing Systems; A Core Marketing Concept," Journal of Macromarketing, 27 (3), 227-42. https://doi.org/10.1177/0276146707302836

Luca, Nadina R., Sally Hibbert and Ruth McDonald (2016), "Toward a Service-Dominant Approach to Social Marketing," Marketing Theory, 16 (2), 194-218. https://doi.org/10.1177/1470593115607941

Marion, Gilles (2006), "Marketing Ideology and criticism: legitimacy and legitimization," Marketing Theory, 6 (2), 245-62. https://doi.org/10.1177/1470593106063985 
Matsumoto, Shigeru ed. (2017), Environmental Subsidies to Consumers: How did they work in the Japanese market?. Routledge.

Moor, Liz (2011), "Neoliberal Experiments: Social Marketing and the Governance of Populations," in Inside Marketing: Practices, Ideologies, Devices, Detlev Zwick and Julien Cayla, eds. 299-319. Oxford: Oxford University Press.

Nishikawa, Issei (2009), The Thought of Hometown, Iwanami Shoten (in Japanese).

Özgün, Aras, Nikhilesh Dholakia and Deniz Atik (2017), "Marketization and Foucault", Global Business Review, 18 (3), suppl: S191-S202. https://doi.org/10.1177/0972150917693335

Peattie, Ken and Sue Peattie (2009), "Social Marketing: A Pathway to Consumption Reduction?," Journal of Business Research, 62 (2), 260-68. https://doi.org/10.1016/i.jbusres.2008.01.033

Peattie, Ken, Sue Peattie and Robert Newcombe (2016), "Unintended Consequences in Demarketing Antisocial Behaviour," Journal of Marketing Management, 32 (17-18), 1588-1618. https://doi.org/10.1080/0267257X.2016.1244556

Skålén, Per, Martin Fougère and Markus Fellesson (2012), Marketing Discourse: A Critical Perspective. Routledge.

Szmigin, Isabelle, Andrew Bengry-Howell, Christine Griffin, Chris Hackley and Willm Mistral (2011), "Social Marketing, Individual Responsibility and the "Culture of Intoxication," European Journal of Marketing, $45 \quad$ (5), https://doi.org/10.1108/03090561111120028

Tadajewski, Mark (2011), "Critical Marketing Studies," in Key Concepts in Critical Management Studies, Mark Tadajewski, Pauline Maclaran, Elizabeth Parsons and Martin Parker, eds. London: Sage, 83-87.

Tadajewski, Mark (2013), "What is Critical Marketing Studies? Reading Macro, Social and Critical Marketing Studies," in Humanistic Marketing, Richard J. Varey and Michael Pirson, eds. Palgrave Macmillan, 39-52.

Truong, V. Dao (2014), "Social Marketing: A Systematic Review of Research 1998-2012," Social Marketing Quarterly, 20 (1), 15-34. https://doi.org/10.1177/1524500413517666 
Truong, V. Dao (2016), "Government-led Macro-social Marketing Programs in Vietnam: Outcomes, Challenges, and Implications," Journal of Macromarketing, 37 (4), 409-25. https://doi.org/10.1177/0276146716660833

Uchiyama, Yu (2010), Koizumi and Japanese Politics: Reform Strategies and Leadership Style. (trans. by Carl Freire), Routledge.

Vargo, Stephen L. and Robert F. Lusch (2004), "Evolving to a New Dominant Logic for Marketing," Journal of Marketing, 68 (1), 1-17. https://doi.org/10.1509/jmkg.68.1.1.24036

Vargo, Stephen L. and Robert F. Lusch (2008), "Service-Dominant Logic: Continuing the Evolution," Journal of the Academy of Marketing Science, 36 (1), 1-10. https://doi.org/10.1007/s11747-007-0069-6

Varman, Rohit, Per Skålén and Russell W. Belk (2012), "Conflicts at the Bottom of the Pyramid: Profitability, Poverty Alleviation, and Neoliberal Governmentality", Journal of Public Policy \& Marketing, 31 (1), 19-35. https://doi.org/10.1509/jppm.10.026

Walters, William (2012), Governmentality: Critical Encounters. Routledge.

Wymer, Walter (2010), "Rethinking the Boundaries of Social Marketing," Journal of Business Research, 63 (2), 99-103. https://doi.org/10.1016/j.jbusres.2009.02.003

Zwick, Detlev, Samuel K. Bonsu and Aron Darmody (2008), "Putting Consumers to Work: 'Co-creation' and new marketing governmentality," Journal of Consumer Culture, 8 (2), 163-96. https://doi.org/10.1177/1469540508090089 